\title{
THE RISE OF FUNDAMENTALISM IN THE MUSLIM WORLD AND THE IMPACT ON WOMEN
}

\author{
A ASCENSÃO DO FUNDAMENTALISMO NO MUNDO \\ MUÇULMANO E SEU IMPACTO SOBRE AS MULHERES
}

João Gallegos Fiuza ${ }^{1}$

\section{Introduction}

This article will analyse the impact of Islamic fundamentalism on gender issues, more specifically on women. The growing problems and threats to Muslim women's health and life in fundamentalist societies make this topic relevant, being one of the most discussed themes among international law, human rights and political science researchers currently. This article will consider the period from the end of the First World War in 1918, when the new geographical, geopolitical and international configurations caused radical changes in the Muslim world, which would cause the new ideologies to confront the implementation of Western values and practices in Muslim societies. Therefore, the research question of this article is about how Islamic fundamentalism has impacted women. The theoretical framework used in this article is based on Thiele, who states that fundamentalist Islam has reflected a predominantly male agenda, reflecting exclusively male concerns, dealing with this groups' activity and ambitions, moving away from issues involving or of concern to women (1986: 30). To answer the research question, the first step will be to verify what Islamic fundamentalism is and its impacts on social and political life. Afterwards, the influence of fundamentalism on women's social and political lives will be researched, to finally analyse the trends that can be observed in Islamic fundamentalism nowadays. The proposed hypothesis to answer the question is that fundamentalism has caused a huge negative impact on women's rights, both in social and political aspects.

\section{The Rise of Islamic Fundamentalism}

Islamic fundamentalism arose around the 1930s and 1940s, both in the Indian subcontinent and in Egypt, due to the dissemination of the ideas of Hassan al-Banna for Jamaat-e-Islami and Sayyid Qutb for the Muslim Brotherhood, respectively (Frey, 2007: 277). Islamic fundamentalism is a radical political ideology created as a response against colonialism and other values brought by Western countries to regions where most population is Muslim, such as capitalism and communism. This ideology understands Islam not simply as a religion, but as a political entity that would rule the behaviour of Muslims in all aspects of life. As Islamism is related to the State, the mentioned rule -

\footnotetext{
${ }^{1}$ MSc in International Security, University of Dundee, UK. Specialist in Islamic Studies, Al Maktoum College, Dundee, UK. Master's candidate in Arab Studies, University of São Paulo, Brazil. Researches contemporary Arab history and politics of the Middle East. Article written for the Advanced Diploma in Islamic Studies, Al Maktoum College. ORCID ID: https://orcid.org/0000-0002-3730-1208. Lattes CV: http://lattes.cnpq. br/7616251378296166. Contact: joao.fiuza@usp.br.
} 
sharia - would be the law of the State, thus, becoming a means of control of the Muslim society within Islamist countries. Another characteristic of this ideology is that it is competitive and confrontational, since it does not accept the idea of living in harmony with Western cultures, and not even allowing the society to manifest any sort of culture or religion that is not Islam (Schwarzmantel, 2008: 121). That is one of the main points that define Islamism, the idea of differentiation from the others, seeking to keep its own culture free from any external influence. Moreover, Islamists aim to unite once again all Muslims within a single State, having a caliph as the civil and religious leader, who would rule through sharia, although the only political sovereign would be divine, which means that no political leader could be pointed but Allah (Husain, 2016: 73-4).

Fundamentalist Islam, or even Islamisation, due to the strictness of its nature, as it can be inferred by the context given above, spreads over all areas of life in a Muslim society, public and private. Including religious practices and the event of Ramadan, in addition to social matters as, for example, segregation, economic reform, the fusion of Islamic thoughts with State laws - through the sharia - and, one of the most remarkable issues, the implications on women's rights, what, in reality, means the diminishing of their rights, especially in the social and political fields (Milton-Edwards, 2005: 202). Therefore, the impact of Islamic fundamentalism on women is obvious, as the practical application of this ideology ends up removing women from social interactions and political life, which is justified by literal interpretations of the Islamic doctrines (Georgakis, 2006: 31).

\section{Social Impact on Women}

The influence of fundamentalism may have much more strict effects on women, as it happens in Afghanistan, where patriarchal tribal traditions insist on keeping their women isolated from having contact with any men but their fathers, brothers or those who would become their husbands. These women can also be killed by male relatives if she does not bleed on her wedding night, in an example of the so-called "honour killings", allowed by Taliban regime - political regime which is Islamic fundamentalist by definition - for any sexual misbehaviour involving women. However, it is relevant to note that practices like the mentioned do not occur only in tribal communities or underdeveloped countries, as the "honour killings" also happen in countries like Iraq, Jordan, Egypt and Syria, seeking to get rid of "shameful women" (Ruthven, 2007: 67).

An example of the social implications on women is what occurs in some regions of Egypt nowadays, where a man, even if not having reached maturity or who is not able to keep a household, can propose marriage to a woman. If the woman rejects the proposal, she will be impious, which means not receiving the expected awards in the afterlife. Therefore, due to this religious fundamentalist rule - in this case, Salafist more exactly - not only men are allowed to freely choose their women, even if they are not economically independent, but women are simply subjugated to men's will in a condition that could bring not only to them, but also to their family, social and financial problems due to establishing a marriage and consequently a new family - through such an inconsequent practice (Husain, 2016: 78).

The consequences of this move for women's rights have, likewise, received mixed interpretations. Most of highly educated people in Muslim countries, or even those who live 


\section{ensaio}

in Muslim communities in Western States, are for a reform in the family and law questions, thus, better adapting Islamic societies to the implications of contemporary times. By doing so, women's rights would be protected, including their role in the marriage and the conjugal union itself, as new procedures would be adopted regarding the minimum ages for marriage, warranting women's consent for the marriage and allowing them to proceed in unilateral divorce. Other situations would also be considered, such as the polygyny matter, its procedures would become more complex due to the high number of implications that it causes in the society (Milton-Edwards, 2005: 117-8); and also, about the extension of women's custody rights over their children, in a measure that not only reinforces the importance of women inside families, but also solidifies the institution of marriage itself. These trends usually receive the approval of many Muslim scholars, who claim that the way that sharia is considered and applied in modern States has maintained many old-minded aspects of male privilege (Kandiyoti, 2009: 94; Ahmed, 2001: 205).

\section{Political Impact on Women}

Regarding women's issues more specifically, it shall be observed that the commonsense in Islamic fundamentalist societies is the idea that Allah put the father as the highest authority for individuals, also emphasising the obligations of this person in the whole community (Ruthven, 2007: 67). Automatically, women will never have any social leading role and would forever be under the authority of fathers or husbands. The concept of authority is extensive in fundamentalist understandings, as it originates from a divine matter.

Currently, many scholars draw attention to what can be called "colonial modernity trends" towards a broader inclusion of women in both society and public life. However, other authors seem to still be too sceptic to understand the importance of what could be called "progressive claims of modernity", which could mean increasing women's social liberty. This evidences the political environment that modernity is involved, causing a regulatory discourse mainly due to the potential change in the relations of subjection (to men) and exclusion (from several social circles). This matter highlights the fact that the modernisation of women's behaviour and social significance would imply in important elements that would grant women citizens not only more liberty of actions, but also of thought (Kandiyoti, 2009: 94-5). Despite seeming like a little detail, this situation may, in truth, bring in short time a big revolution to States where fundamentalist Islam is still a reality, once external values and thoughts would be claimed to be considered and applied to Muslim women, allowing them to have increasing rights and liberty in all aspects of life, principally in what refers to human rights.

\section{Trends of Women Issues in Islamic Fundamentalist States}

Globalisation is spreading not only information, trade and people throughout the world, but also values. Inevitably, the values disseminated by States that have greater influence worldwide are much more likely to reach Muslim societies, including fundamentalist ones. Consequently, modernisation is a matter that fundamentalist societies will undoubtedly have to cope with, despite the fact that the traditionalist nature 
of fundamentalist ideologies would, initially, reject any foreign idea that poses any kind of threat to traditional Muslim values, as history has already shown in recent years (Mulack, 2006: 303).

The case of Hezbollah is an example of the inclusion of modern values in Islamic fundamentalist philosophies, it preaches an egalitarian treatment for all women in the social and economic fields, i.e., granting them the right to assume roles and responsibilities previously denied by society. At the same time, Hezbollah understands that both international and regional treaties must be ratified, moving towards human rights - including women's rights as a consequence. By analysing these arguments, it can be observed that these cases demonstrate that the legislation in fundamentalist Islamic societies can be originated from principles of human rights ethics, not only from Islamic jurisprudence. In addition, Hezbollah does not show any reservation on extending social, political and consequently economic rights to women citizens, in what can be considered an important evolution in Islamic fundamentalism, due to the traditional ban on women's rights implied in fundamentalist philosophy. Such modernisation would obviously face controversies, like what occurred with religious scholars that argued that those substantial changes would imply on critical aspects of their society, since the protection of women's rights would interfere on aspects of personal status law, which is strictly based on sharia, subsequently demanding a conservative interpretation (Dionigi, 2014: 125-131).

All issues surrounding fundamentalist Islam are deemed to form, somehow, a "world of men", since this is how male authors describe it, in a completely masculinised picture that can be confused with the absolute truth. However, this environment is starting to change due to the efforts of women to integrate themselves into world ideas, even if slowly. That means that women, more than ever, are into activities to research and disseminate values and information about women's and human rights issues, for example, things that have direct impact on the ideologies surrounding them. By doing so, women confront ideologically and rationally the men who keep them chained in ignorance and traditions that foster some forms of fundamentalist ideologies (Milton-Edwards, 2002: 43). Notwithstanding, today women are usually recognised as scholars only in the sphere of gender and Islam, probably because these themes are the ones that cause more direct and constant impacts on their lives, what makes them unable to have voice yet.

\section{Conclusion}

The unfair condition of women in fundamentalist Islamic societies show signs of improvements and changes, due to women's own efforts and to the dissemination of international values linked to human rights. However, their voices still need more support, what could be achieved through a more relevant political engagement, mainly from abroad, that could also bring massive support from the international community, causing political pressure on fundamentalist Islamic governments so they recognise the necessity of change, ensuring women rights that could give them conditions not only of living in fairer societies, but also of developing their full potentials. Following these thoughts, women are publicly questioning and confronting the patriarchal order imposed by Islam. The women's fight for their rights in fundamentalist Islamic States, as Badran (2013: 1201), already observed, could soon bring them much more egalitarian life conditions. 


\section{Bibliography}

Ahmed, A. Islam Today. London: I. B. Tauris, 2001.

Badran, M. Political Islam and Gender. The Oxford Handbook of Islam and Politics, pp. 112123. Oxford: Oxford University Press, 2013.

Dionigi, F. Hezbollah, Islamist politics, and international society. New York: Palgrave MacMillan, 2014.

Frey, R. J. Fundamentalism. New York: Facts on File, 2007.

Georgakis, A. Bosnia and Herzegovina. Muslim Cultures Today - A Reference Guide, pp. 2738. Westport: Greenwood Press, 2006.

Husain, E. Islamic Fundamentalism. Fundamentalisms - Threats and ideologies in the modern word, pp. 73-80. London: I B Tauris, 2016.

Kandiyoti, D. Islam, Modernity and the Politics of Gender. In: M. K. Masud, A. Salvatore \& M. v. Bruinessen, eds. Islam and Modernity - Key Issues and Debates, pp. 91-124. Edinburgh: Edinburgh University Press, 2009.

Milton-Edwards, B. Researching the Radical - The quest for a new perspective. Interpreting Islam, pp. 32-50. Thousand Oaks: Sage, 2002. Islamic Fundamentalism since 1945. Abingdon: Routledge, 2005.

Mulack, G. Dialogue and Cooperation with Islamic World. Islamic education, diversity and national identity: Dînî madâris in India post 9/11, pp. 301-9. Thousand Oaks: Sage, 2006.

Ruthven, M. Fundamentalism - A Very Short Introduction. Oxford: Oxford University Press, 2007.

Schwarzmantel, J. Ideology and Politics. Thousand Oaks: Sage, 2008.

Thiele, B. Vanishing acts in social and political thought: tricks of the trade. Feminist Challenges: Social and Political Theory. Sidney: Allen and Unwin, 1986.

Texto recebido em: 30 de Novembro de 2017 Aprovado para publicação em: 03 de Maio de 2018 